This item was submitted to Loughborough's Research Repository by the author.

Items in Figshare are protected by copyright, with all rights reserved, unless otherwise indicated.

\title{
The role of bond finance in firms' survival during the Asian crisis
}

PLEASE CITE THE PUBLISHED VERSION

PUBLISHER

(c) Loughborough University

VERSION

VoR (Version of Record)

LICENCE

CC BY-NC-ND 4.0

REPOSITORY RECORD

Spaliara, Marina-Eliza, and Serafeim Tsoukas. 2019. "The Role of Bond Finance in Firms' Survival During the Asian Crisis". figshare. https://hdl.handle.net/2134/5454. 
This item was submitted to Loughborough's Institutional Repository (https://dspace.lboro.ac.uk/) by the author and is made available under the following Creative Commons Licence conditions.

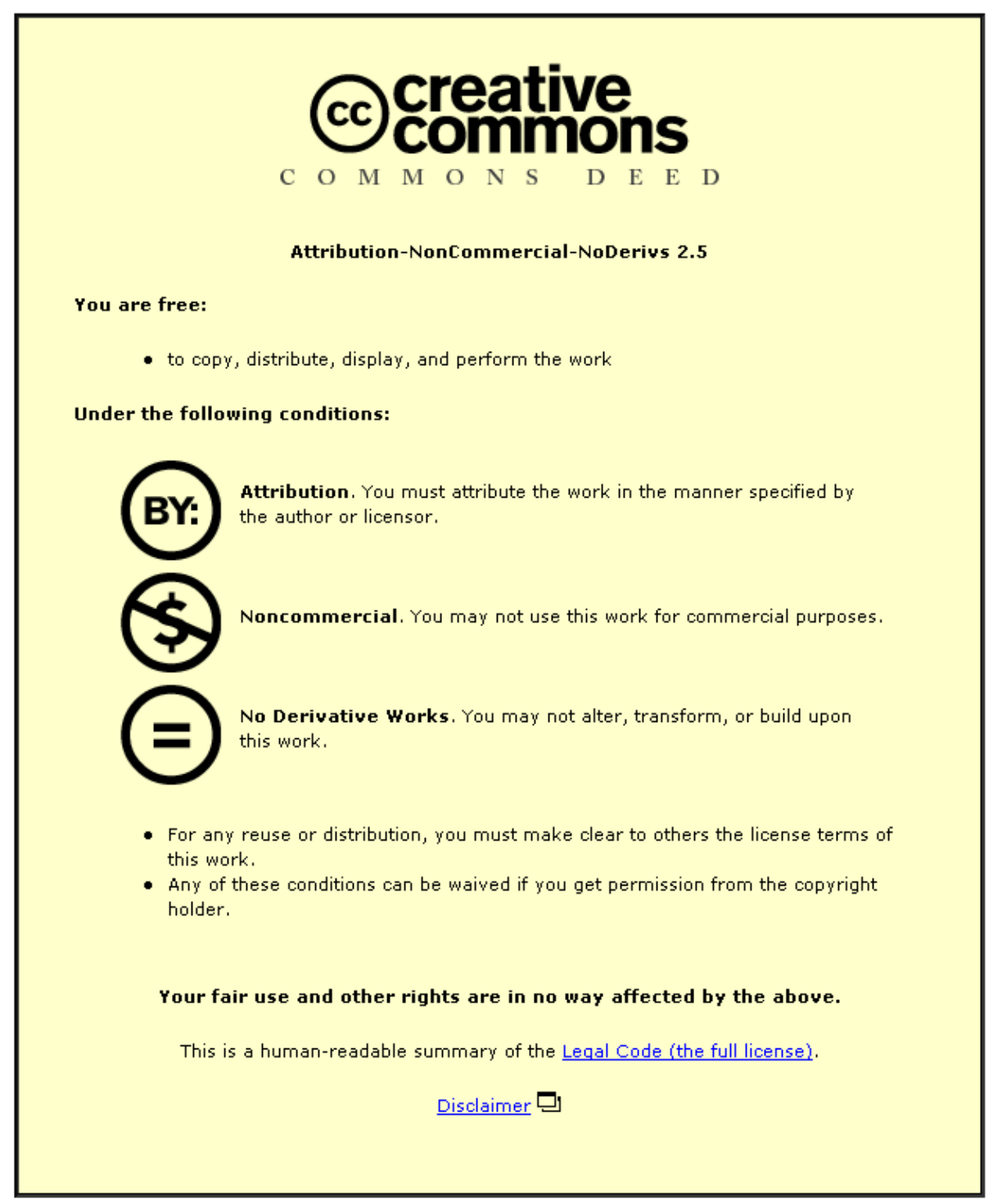

For the full text of this licence, please go to: http://creativecommons.org/licenses/by-nc-nd/2.5/ 
ISSN 1750-4171

\section{DEPARTMENT OF ECONOMICS}

\section{DISCUSSION PAPER SERIES}

\section{The role of bond finance in firms' survival during the Asian crisis}

Marina-Eliza Spaliara, Serafeim Tsoukas

$$
\text { WP } 2008 \text { - } 17
$$

Dept Economics 


\title{
The role of bond finance in firms' survival during the Asian crisis*
}

\author{
Marina-Eliza Spaliara \\ Department of Economics \\ Loughborough University \\ LE11 3TU, UK
}

\author{
Serafeim Tsoukas \\ School of Economics \\ University of Nottingham \\ NG7 2RD, UK
}

November 2009

\begin{abstract}
In this paper we assess the effects of bond financing on firms' survival during the 1997-98 Asian crisis. Using a novel database covering the period 1995 to 2007 for five Asian economies most affected by the crisis - Indonesia, Korea, Malaysia, Singapore and Thailand - we find strong evidence that the Asian crisis affected both directly and indirectly (through interactions with financial indicators) the probability of survival. More importantly, we show that bond issuers, irrespective of the currency denomination, are more likely to survive compared to non-issuers. Nevertheless, only firms issuing bonds in local currency are shielded from the adverse effects of the crisis.
\end{abstract}

Key words: Bond financing, Financial crisis, Firm survival, East Asia JEL: F32, F34, G15, L20

\footnotetext{
*Correspondence to Serafeim Tsoukas; Email: serafeim.tsoukas@nottingham.ac.uk. The authors gratefully acknowledge the support of the Hong Kong Institute of Monetary Research, Hong Kong and their generous hospitality during the period that this paper was prepared. We have received helpful comments from Michael Bleaney, Spiros Bougheas, Hans Genberg, Sourafel Girma, Alessandra Guariglia, Laurence Fung, Galina Hale, Jacques Mairesse, John Tsoukalas and seminar participants at the 2009 EARIE conference in Ljubljana. We thank Kenneth Chow for excellent research assistance. Financial support through the UK Economic and Social Research Council Grant Ref: PTA-026-27-1790 (Tsoukas) and the European Cooperation in Science and Technology, Grant Ref: COST ISO701 (Spaliara) is gratefully acknowledged. Any remaining errors are our own.
} 


\section{Introduction}

What is the effect of bond financing on corporate failures? Bolton and Freixas (2008) argue that bond financing, as a form of long-term finance, does not expose firms to the risks of bank runs and systemic crises. While bank-financed firms are fully exposed to the risk of bank loans, bond-financed firms are shielded from the adverse effects of a financial crisis and therefore are more likely to survive. It is generally accepted that during hard times lenders are more likely to withhold funds and interrupt lines of credit to less creditworthy firms forcing some of them to fail.

The main goal of this paper is to quantify the effects (and assess the importance) of bond financing in influencing firm survival. We do this using a novel dataset that combines several sources including Thomson Financial Primark, Bondware, Bloomberg, Zephyr and the Asian Development Bank. We then go further to examine if bond-financed firms are shielded from the adverse effects of the Asian crisis. Given that bond markets in Asia were largely underdeveloped during the crisis it is not clear whether access to financial markets dampened the effects of the crisis. We are able therefore to assess the potential offsetting role of bond finance in determining business failure. The East Asian twin crisis (currency and banking crisis) is an ideal setting to study the link between firms' survival and access to bond markets because during this period most corporations were heavily dependent on domestic and foreign bank finance to supplement internal funds for investment, with smaller and medium sized enterprises almost exclusively reliant on domestic bank loans. When the crisis erupted the funding to banks and then to corporations fell dramatically, and in the absence of local corporate bond markets to provide an alternative source of funding the effects of the crisis were amplified (Eichengreen et al. (2006)).

The theoretical motivation for the role of bond financing in survival is related to the 'track record' reputation that firms can establish in the bond market. Reputation, which is a concept that was made popular by Diamond (1991), is based on the history of firms' credit risk and can be used to access the bond market under favourable terms. Firms with 
access to bond markets are able to bear the significant fixed cost of issuing a bond, which is generally higher than the fixed cost of taking out a bank loan, and thus to give a good signal to lenders for their reputation. These reputational effects may become even more relevant during periods of economic crises where bond issuers might be able to overcome financial problems by extending external finance and re-negotiating existing bank loans. For example, banks could re-schedule the loans for issuers and trade creditors may extend their funding to support customers with long-lasting relationships. This may not be the case for bank dependent non-issuing firms that do not have established a track record in the market. Nonissuers therefore may find it more expensive to obtain external funding at times of hardship. These considerations suggest that reputational effects for bond issuers can be beneficial for their survival, especially during economic crises.

Figure 1 presents prima facie evidence suggesting that East Asian firms with access to bond markets may be better equipped to weather systemic crises. Using our data to compare issuers and non-issuers, we show that the latter category exhibits significantly more failures throughout the sample period. Importantly, this difference is even more pronounced during the crisis. For example, in the year 1997 the number of failing firms that do not have access in the bond market (non-issuers) is about 12 times higher compared to bond issuers. This startling difference between issuers and non-issuers maybe explained by the fact that the former group of firms has an established 'track record' in the market and therefore is associated with the lower degree of informational asymmetry.

Our work is related to three different strands of literature. First, we build on the empirical and theoretical literature that looks at the importance of financial status and borrowing constraints on firms' survival and concludes that firms in bad financial shape are more likely to fail (see Zingales (1998); Bunn and Redwood (2003); Clementi and Hopenhayn (2006); Farinha and Santos (2006) and Bridges and Guariglia (2008)). A second relevant strand of literature has emphasised the important role of macroeconomic environment on survival. Alvarez and Görg (2009) offer evidence from Latin America and Bhattcharjee et al. (2009) 
from the UK showing that changes in the macroeconomic environment may interact with relevant firm and industry features in amplifying exit hazards. A third related line of work is the literature on the emerging economies financial development. According to BIS (2005) reports, the development of the financial system in general will help firms to better endure financial crises and avoid currency mismatches. However, the progress of development in Asia, especially for corporate bonds, remains painfully slow (Borensztein et al. (2006) and Eichengreen et al. (2006)).

The value added of the present paper is threefold. First, we look at the role of bond financing in firms' survival. It is well known that in the presence of information asymmetries in capital markets, firms prefer internal to external finance, but at some point as firms grow, self-funding typically becomes insufficient to finance their investment projects and so they turn to sources of external finance from the markets, in preferential order for equity, debt and banks. ${ }^{1}$ In this paper, we focus on bond finance and investigate whether being a bond issuer is more of an advantage in attenuating failure hazards. We also consider the currency denomination of bonds, distinguishing between domestic and foreign issued bonds. Second, we examine the link between firm survival and the 1997-98 East Asian crisis controlling for a number of firm-specific, industry-specific indicators and macroeconomic factors. We explore the direct and the indirect effect (through interactions with financial indicators) of the financial crisis on firm survival, using comparable micro level panel of five economies Indonesia, Korea, Malaysia, Singapore and Thailand - that were hit the hardest during this period. Finally, the implications of the crisis on survival are assessed for bond issuers and non-issuers as well as for domestic and foreign currency bonds.

The remainder of the paper is laid out as follows. Section two illustrates the empirical specifications and the econometric methodology. In Section three we present a descriptive analysis of our data. Section four presents the empirical evidence. In section five we check the robustness of our findings. Section six concludes the paper.

\footnotetext{
${ }^{1}$ This sequence arises from the 'pecking-order' hypothesis by Myers and Majluf (1984) and a literature has developed to explore the composition of external finance based on this hypothesis.
} 


\section{Empirical implementation}

Probit models are commonly used in the related empirical literature (for example Zingales (1998); Greenaway et al. (2008) and Baggs et al. (2009)). However, the issue of endogeneity in our empirical specifications, which are enriched with a set of firm-specific financial indicators, is likely to be of particular importance. ${ }^{2}$ We address this issue by allowing the firm-specific variables to be endogenous and then instrumenting for them through a two-stage procedure. Our approach to employ instrumental variable techniques in the estimations is formally justified by using a Wald test of exogeneity. We report p-values of the test at the foot of the tables of results. In all cases the Wald test emphatically rejects the null of exogeneity in our regressors vindicating our endogenous approach.

Our empirical specifications are motivated by Clementi and Hopenhayn (2006) who develop a theory of borrowing constraints and study its implications for firm survival among other firm dynamics. Their model generates a role for capital structure in an asymmetric information setup. ${ }^{3}$ We specify a baseline model as follows:

$$
\begin{aligned}
\operatorname{Pr}\left(F A I L_{i t}=1\right)=F\left(a_{0}+\right. & a_{1} L E V E R A G E_{i t}+a_{2} P_{R O F I T}+a_{3} C O L L A T E R A L_{i t}+a_{4} S I Z E_{i t} \\
& \left.+a_{5} S I Z E_{i t}^{2}+a_{6} A G E_{i t}+a_{7} E X C H A N G E_{t}+a_{8} M E S_{j}+\epsilon_{i t}\right)
\end{aligned}
$$

where FAIL is a dummy variable that equals 1 if firm $i$ fails in year $t$, and 0 otherwise. We define a firm as failed in a given year when its company status is that of dead. ${ }^{4} F($. denotes the standard normal distribution function.

To incorporate a role for finance in the survival model, as suggested by Clementi and

\footnotetext{
2 As it has been emphasised for linear models, endogeneity in binary choice models results in biased coefficients and, therefore, incorrect inferences ( Maddala (1983) and Rivers and Vuong (1988)).

${ }^{3}$ The theoretical frameworks on survival were firstly introduced by Hopehayn (1992) and Jovanovic (1982) without considering a role for moral hazard.

${ }^{4}$ We elaborate on the construction of the failure dummy in the next section. Note that we use the terms failure and survival interchangeably.
} 
Hopenhayn (2006), we consider three dimensions of financial health from the balance sheet, namely leverage, profitability and collateral assets. The financial condition of the firm is an important determinant of firm failure as argued by Zingales (1998), Bunn and Redwood (2003) and Bridges and Guariglia (2008). Considering the likely response of leverage ( $L E V E R A G E)$, as measured by the firm's total debt to total assets, we remark that high levels of existing debt are associated with a worse balance sheet situation, which would increase moral hazard and adverse selection problems, and lead to the inability of firms to obtain external finance at a reasonable cost (see Levin et al. (2004)). Zingales (1998), Farinha and Santos (2006) and Bridges and Guariglia (2008) show that highly leveraged carriers, start-ups and domestic firms are less likely to survive. We expect therefore a positive relationship between leverage and the probability of failure.

The next financial component is a profitability ratio (PROFITABILITY) defined as the ratio of the firm's profits before interests and tax to its total assets. Following Bunn and Redwood (2003) and Bridges and Guariglia (2008) we use this measure to proxy for the firm's ability to generate profits. We anticipate a positive relationship between profitability and the likelihood of survival.

As an additional financial indicator we include a measure of tangible assets, which indicates the firm's ability to pledge collateral for debt finance (COLLATERAL). Assets that are more tangible sustain more external financing because tangibility increases the value that can be recaptured by creditors in case of borrower's default. Collateral has also been found to affect firms' chances of survival. Farinha and Santos (2006) and Bridges and Guariglia (2008) document that firms with a larger fraction of tangibles in their balance sheets are more likely to survive for a longer period of time. Thus, we expect a negative relationship between collateral and the incidence of failure.

In addition to financial characteristics our specifications include a choice of control variables guided by the existing empirical and theoretical literature on the determinants of firm survival. It is recognised that a firm's size plays an important role in determining firm fail- 
ure, (Clementi and Hopenhayn (2006)), and is expected to decrease the incidence of failure. Large firms tend to face lower barriers in accessing the capital markets, while smaller firms with more severe information problems tend to face a higher risk of insolvency and illiquidity and consequently a higher risk of failure (Mata and Portugal (1994); Audretsch and Mahmood (1995) and Dunne et al. (1998)). Hence, we introduce size (SIZE) measured as the logarithm of the firm's real total assets. ${ }^{5}$ We also incorporate its square $\left(S I Z E^{2}\right)$ to allow for non-linearities. Further, we include firms' age since firms with an established track record are less likely to fail than those that are younger because new entrants face a greater risk of failure due to the 'liability of newness' effect (Stinchcombe (1965)). A large number of empirical and theoretical papers have shown that younger firms are more likely to fail (e.g Jovanovic (1982); Audretsch and Mahmood (1995) and Clementi and Hopenhayn (2006)) and this would be the case both for domestic and multinational firms as noted by Görg and Strobl (2002). Thus we introduce age $(A G E)$ which measures the number of years a firm has been listed on the stock exchange.

We also attempt to control for macroeconomic and industry-specific conditions in our models. To this end we control for macroeconomic effects by adding the exchange rate, which measures the exchange rate environment. Baggs et al. (2009) document a negative association between survival and appreciation of the Canadian dollar. We expect the exchange rate (EXCHANGE) to be positively associated with the firm's probability to fail. To control for economies of scale of the industry, we add the minimum efficient scale of the industry $(M E S)$, measured as the $\log$ of median output in sector $j .{ }^{6}$ Empirical evidence concerning the influence of MES on firm survival is ambiguous. At one extreme, one might expect firms entering industries with large minimum efficient scale to have lower probabilities of survival than firms entering other industries, Mata and Portugal (1994). At the other extreme, industries with high MES are usually also industries showing high price cost margins, which

\footnotetext{
${ }^{5}$ To check the robustness of our results we use two alternative measures of size such as the number of employees and real sales. Our results, not reported here for brevity, remain largely unaffected.

${ }^{6}$ We also employ the MES defined as the log of median employment size in the industry, used by Görg and Strobl (2003). Results remain largely unchanged.
} 
should increase firm survival (Audretsch (1991)). We expect MES to significantly affect firm survival but its sign will be determined by the data.

In order to establish whether firms' survival prospects change during periods of adverse economic events compared to tranquil periods, we model the determinants of firm survival and check whether the occurrence of a financial crisis is a statistically significant determinant of firms' probability of failure. To do so we include a time period dummy (CRISIS) that takes the value of one in years 1997-98, and zero otherwise. The direct effect of the financial crisis on failure is shown from the sign and significance of the coefficient $a_{9}$.

$$
\begin{aligned}
\operatorname{Pr}\left(F A I L_{i t}\right. & =1)=F\left(a_{0}+a_{1} L E V E R A G E_{i t}+a_{2} \text { PROFIT } i t+a_{3} C O L L A T E R A L_{i t}+a_{4} S I Z E_{i t}\right. \\
& \left.+a_{5} S I Z E_{i t}^{2}+a_{6} A G E_{i t}+a_{7} E X C H A N G E_{t}+a_{8} M E S_{j}+a_{9} C R I S I S_{i t}+\epsilon_{i t}\right)
\end{aligned}
$$

To examine the differential impact of the Asian crisis on firm survival, we include interaction terms of the crisis dummy with the financial indicators [Financial indicator*Crisis, Financial indicator* $(1-$ Crisis $)]$. This specification provides us with the indirect effect of the financial crisis on business failures, since we allow for the fact that firms with varying levels of profits, debt and collateral might respond to the crisis disproportionately.

At the next stage we specify an empirical model including the term $B O N D$ which is a dummy equal to 1 if firm $i$ issues a bond in year $t$, and 0 otherwise. Thus, we record the bond history in each firm. This specification is aimed at capturing the direct impact of bond finance on firm survival. The direct effect is judged from the sign and significance of the coefficient $a_{9}$. The estimated model is specified as follows: 


$$
\begin{aligned}
\operatorname{Pr}\left(F A I L_{i t}=\right. & 1)=F\left(a_{0}+a_{1} L E V E R A G E_{i t}+a_{2} P R O F I T_{i t}+a_{3} C O L L A T E R A L_{i t}+a_{4} S I Z E_{i t}\right. \\
& \left.+a_{5} S I Z E_{i t}^{2}+a_{6} A G E_{i t}+a_{7} E X C H A N G E_{t}+a_{8} M E S_{j}+a_{9} B O N D_{i t}+\epsilon_{i t}\right)
\end{aligned}
$$

Equation (2.3) is modified to include interactions between bond issuers and non-issuers with the crisis dummy to show variations in firms' survival prospects. This test is motivated by the theoretical argument by Bolton and Freixas (2008), that bond-financed firms are shielded from the direct effect of a financial crisis. We focus on the sign and significance of the coefficients $a_{9}$ and $a_{10}$, where we suggest that the influence of bond finance is determined in conjunction with the Asian crisis.

$$
\begin{array}{r}
\operatorname{Pr}\left(F A I L_{i t}=1\right)=F\left(a_{0}+a_{1} L E V E R A G E_{i t}+a_{2} P R O F I T_{i t}+a_{3} C O L L A T E R A L_{i t}+a_{4} S I Z E_{i t}\right. \\
+a_{5} S I Z E_{i t}^{2}+a_{6} A G E_{i t}+a_{7} E X C H A N G E_{t}+a_{8} M E S_{j}+a_{9} \text { BOND }_{i t} * C R I S I S_{i t} \\
\left.+a_{10}\left(1-\text { BOND }_{i t}\right) * C R I S I S_{i t}+\epsilon_{i t}\right)
\end{array}
$$

Finally, we model the differential impact of currency denomination of bonds on the incidence of failure during the 1997-98 crisis.

\section{Data}

\subsection{Data description}

The data for this paper are drawn from different sources including Thomson Financial Primark, Bondware, Bloomberg, Zephyr and the Asian Development Bank. These are combined in a new way to cast light on the probability of failure in the Asian region. The data cover 
firms in emerging Asia mostly affected by the 1997-98 crisis - Indonesia, Korea, Malaysia, Singapore and Thailand. The time period is 1995 through 2007, which covers the period of the East Asian crisis and the aftermath of the crisis which has been characterised by a significant regional development in terms of size, liquidity and sophistication.

The Thomson Financial Primark database offers balance sheet and profit and loss accounts data for firms in the East Asian region. Our initial dataset includes a total of 28,445 annual observations on 4,651 companies. We provide information on financial accounts and ratios for Asian firms operating in all sectors of the economy.

The data on bond issues are drawn from Bondware and Bloomberg. We use Bondware to identify all corporate bonds issued in international markets and we use Bloomberg to identify similar data for firms that issue bonds in the domestic Asian markets. Our coverage of bond issues therefore embraces both firms with issues in hard currencies, which are almost exclusively US dollar denominated, and firms with local currency denominated bonds. Before the crisis, issuance in local currency bonds by corporations was very limited but in the postcrisis period it went up significantly (see Fernandez and Klassen (2004) and Burger et al. (2009)). In our data $55 \%$ of bonds are denominated in domestic currency and the remaining $45 \%$ in foreign currency. Data on exchange rates, which are meant to proxy for changes in the macroeconomy, are taken from the Asian Development Bank.

We use Zephyr to obtain data on mergers and acquisitions for the sampled firms. Thomson Financial Primark reports firms as 'dead' but it may be possible that some firms could be recorded as 'dead' not because they failed but because they merged with another firm instead. Employing Zephyr we are able to identify and drop those firms that are mistakenly coded as 'dead' in our data. This will ensure that our dependent variable has been accurately constructed to capture firms that failed and did not exit the sample due to mergers and acquisitions.

Following normal selection criteria used in the literature, we exclude companies that did not have complete records for all explanatory variables and firm-years with negative sales. To 
control for the potential influence of outliers, we exclude observations in the 0.5 percent from upper and lower tails of the distribution of the regression variables. Our combined sample contains data for 358 firms in Indonesia, 917 in Korea, 871 in Malaysia, 596 in Singapore and 530 in Thailand, a total of 3,272 firms. Finally, by allowing for both entry and exit, the panel has an unbalanced structure which helps mitigate potential selection and survivor bias.

\subsection{Sample analysis}

We begin our analysis by showing the evolution of failures over time in Figure 2. This figure shows that our sample is dominated by firms that failed in 1997 which coincided with the onset of the Asian crisis. Apart from this period the distribution of failures over time is reasonably stable. Summary statistics for the variables used in our empirical analysis are provided in Table 1. Means and standard deviations of the firm-specific variables and financial indicators are presented for the total sample (column 1), for failed and surviving firms (columns 2 and 3) and for those firms that are issuers and those that are non-issuers (columns 5 and 6). Further, the p-values of a test for the equality of means are presented in columns 4 and 7. Looking at columns 2 and 3 we observe that surviving firms are larger than failed firms. This finding implies that firm size is an important determinant in business failures. The proxy for age shows that survivors are also longer listed on the stock exchange suggesting that those firms that are able to build track record in the market are more likely to reduce the incidence of failure. Regarding the financial variables, surviving firms display higher levels of profitability, they are more collateralized and less indebted. Further, they are more likely to be bond issuers and less likely to be affected by the crisis. These differences between sub-samples are statistically significant in all cases.

On the basis of bond financing (columns 5 and 6), we observe that the average firm's failure rate for non-issuers $(0.106)$ is almost 1.5 times higher than the corresponding figure for bond issuers (0.066). These statistics highlight the importance of bond financing in at- 
tenuating exit hazards. We find that firms with access to bond finance are larger, confirming the information asymmetry problem that small firms face (see Calomiris et al. (1995)). We also observe that bond issuers are more leveraged, consistent with the notion that higher levels of leverage is often perceived as a good sign of borrowing capacity in the bond markets (see Dennis and Mihov (2003)). They also have lower levels of profitability and collateral compared to non-issuers. The former finding shows that more profitable firms may find it optimum to delay their entry to bond markets consistent with the limited liquidity assumption. The latter result implies that having more tangible assets is not necessarily an advantage for bond issuance, unlike for bank finance where tangible assets can be pledged as collateral. In addition, bond issuers are less likely to fail during the financial crisis (0.079) in contrast with non-issuers $(0.143)$.

In summary, these preliminary statistics suggest that firms' failure rates are largely related to bond finance, financial healthiness and the crisis. It remains to be seen, however, whether these findings continue to hold when we control for a number of factors which are known to play a role in survival models. In the sections that follow we provide formal econometric analysis of the determinants of firm failures, the effect of financial crisis, and the role of bond financing.

\section{Main results}

\subsection{The direct and indirect effect of the Asian crisis on failure}

We begin our enquiry with a baseline model of business failure as shown in Equation (2.1).

Table 2, column 1 summarises the results of the IV Probit where the probability of failure is modelled as a function of the firm-specific control variables, financial indicators, industry characteristics and macroeconomic conditions. This model is aimed at evaluating the impact of financial health on survival probabilities. The predicted probability of exit, evaluated at the mean of the independent variables is $7.3 \%$, which is close to the actual exit rates reported 
in the summary statistics. To provide some interpretation of the estimated coefficients in column 1, we also report the marginal changes, evaluated at the sample means for each variable.

Financial indicators have the expected impact on firms' failure. In particular, firms with high levels of $L E V E R A G E$ face higher probabilities of failure compared to those with low leverage confirming previous reported empirical evidence (Zingales (1998); Farinha and Santos (2006) and Bridges and Guariglia (2008)). High levels of debt would increase moral hazard and asymmetric information problems, and would lead to a higher probability of failure. The effect is economically important since a one percent increase in leverage would raise the probability of failure by $2.7 \%$. This implies a reduction in the predicted exit probability by $37 \%(2.7 / 7.3)$.

Next, PROFITABILITY measures the extent to which high-profitable firms face a lower risk of failure. It enters with the expected negative sign implying that an increase in profitability ratio lowers the hazard of failure. Marginal changes suggest that a one percent increase in firms' profits would decrease failure rates by $0.07 \%$. This result is consistent with previous findings that more profitable firms are less likely to fail (Bunn and Redwood (2003) and Bridges and Guariglia (2008)).

The coefficient on COLLATERAL, the proxy for the degree of firms' collateralization, attracts the expected negative sign and it has a highly significant impact on firms' failure prospects. Firms with high levels of tangible assets are able to pledge collateral and to obtain more external funding but also to pursue risk-shifting strategies (Bridges and Guariglia (2008) and Farinha and Santos (2006)). This effect is economically important since increasing collateral by one percent would reduce the incidence of failure by $4.86 \%$.

With respect to our firm-specific controls, the results on $S I Z E$ and $S I Z E^{2}$ indicate that there is a non-linear relationship between firm size and the likelihood of survival. A significant coefficient of the squared logarithm of real total assets shows that the advantages of a bigger size decrease with increasing size, with the turning point being 12 . The coefficient on firm 
$A G E$ exerts a negative and significant impact on failure. This finding is in line with previous theoretical and empirical evidence which shows that younger firms that lack reputation in the market are more likely to fail (e.g Jovanovic (1982); Audretsch and Mahmood (1995) and Clementi and Hopenhayn (2006)).

The results on the $M E S$ and the exchange rate $(E X C H A N G E)$ behave as conjectured. Firms operating in industries with high MES are more likely to survive, which is consistent with Audretsch (1991), whereas the proxy for the macroeconomic condition attains a positive effect on failure which supports the theory that a stronger local currency raises the probability of firms to fail (Baggs et al. (2009)).

To assess the role of the East Asian financial crisis on firms' likelihood of failure, we first focus on the direct impact of the crisis on the probability of survival using the time-period CRISIS to indicate that firms faced the Asian crisis by estimating Equation (2.2). The third column of Table 2 shows that the coefficients on the control variables size, size squared, age, MES and EXCHANGE retain their signs and their significant impact on survival. As before, financial indicators also affect significantly firms' probability of failure. Focusing on the impact of the financial crisis dummy on the likelihood of failure we observe that during 1997 and 1998, East Asian firms were more likely to fail. More precisely, the coefficient on the dummy shows the positive and highly significant effect on the hazard of failure. Looking at column 4 , the marginal change is $7.71 \%$ supporting the view that during downturns economic activity faces a general slowdown which is likely to affect bank credit, business profitability and survival among other firms' real decisions.

To further scrutinise the impact of the financial crisis on the hazard of failure, we look into the indirect effect (through interactions with financial characteristics) of the crisis dummy on failure. We interact our financial indicators, leverage, profitability and collateral, with the Crisis and (1-Crisis) dummy to capture the sensitivity of survival to financial indicators in and out of the financial crisis. Imperfect capital markets generate a transmission mechanism through which an economic shock can generate large and persistent domestic balance sheet 
effects. ${ }^{7}$ Previous evidence suggests that there is significant difference in the response of firms' real activities in periods of recession versus non-recession (Gertler and Gilchrist (1994)). Thus, our objective is to check whether the impact of the financial crisis on failure can be amplified by firms with weak financial health.

The results in Table 3 reveal that all financial indicators (with the exception of profitability) present higher coefficients during the crisis compared to their coefficients out of the crisis and these are statistically different from each other. ${ }^{8}$ The findings are economically important since a percentage increase in leverage would raise the probability of failure by $8.3 \%$ during the recession period and by only $1.07 \%$ during tranquil periods. The importance of good financial health in periods of economic slowdown is also observed on the coefficient for collateral. High levels of tangible assets boost the survival prospects of East Asian firms especially during the crisis. Marginal changes suggest that a percentage increase in collateral would reduce the incidence of failure by $22.43 \%$ during the crisis and by $15.45 \%$ out of the crisis. To summarise, we find that financial indicators are more important in explaining business failures during the financial crisis compared to tranquil periods, revealing that firms in good financial shape face higher probabilities of survival.

\subsection{Bond finance, survival and the Asian crisis}

The East Asian financial system suffered severe damages during the crisis primarily due to the underdeveloped bond market and the weak banking sector. One basic premise of this paper is that access to bond finance is associated with the establishment of reputation in the market (Diamond (1991)). If reputational effects are in play we should expect to find bond issuers to be less likely to fail, everything else equal. In addition, we anticipate reputation to be of particular importance during the crisis where non-issuers, which are more informational

\footnotetext{
${ }^{7}$ According to the financial accelerator theory (Bernanke et al. (1999)), procyclical movements in the firm's balance sheets and net worth, and credit constraints can amplify and propagate the real or monetary policy shock.

${ }^{8}$ The p-values for the test of equality for the coefficients on leverage and collateral are as follows: 0.007 ; 0.018
} 
opaque and lack track record, will have a higher probability of failure.

In Table 4, columns 1 and 2, we show the direct impact of bond finance on failure as shown in Equation (2.3). In columns 3 and 4 we present the sensitivity of firms' survival probabilities to bond finance during the Asian crisis as shown in Equation (2.4). All the control and financial variables are correctly signed and retain their significance. Turning to the results of our main interest, we observe that the coefficient on the bond issuance dummy (column 1) exerts a negative impact on the likelihood of failure. Marginal effects suggest that the change in the likelihood of failure associated with a change in the dummy from 0 to 1 (non-issuer to issuer) is $5 \%$. This implies a reduction in the predicted exit probability by $71 \%(5 / 7)$. Firms that are able to borrow through the issuance of bond debt are those that can bear the significant fixed cost of accessing the bond market, which is higher than the fixed cost of taking out a bank loan, and signal their lenders for their good reputation. Bond-financed firms might be able to overcome any credit burden and thus they are less likely to fail. This empirical result supports the argument of good reputation established through bond issuance. Further, we find that bond issuers remain unaffected during the crisis (column 3). The importance of reputation may become even more relevant during periods of economic crises where bond issuers might be able to overcome financial problems by extending external finance and re-negotiating existing bank loans. This finding confirms the argument of Bolton and Freixas (2008) that 'bond issuers are shielded from the direct effect of a financial crisis' (p. 37). ${ }^{9}$ The opposite is true for non-issuers (column 4). Switching a firm's status from bond issuer to non-issuer would raise the incidence of failure by $8 \%$.

Having presented the beneficial effects of bond issuance, we now check whether there is a differential impact of currency denomination of bonds on firms' failure probabilities during the crisis. In Table 4 we presented evidence that bond issuers are shielded from the crisis due to reputational effects. However, one plausible question is whether this argument holds if

\footnotetext{
${ }^{9}$ It should be noted, however, that access to bond finance may not always be a panacea for all economies. During the 1997-98 crisis, corporate bond markets were largely underdeveloped and quickly evaporated when they needed the most. Eichengreen et al. (2006) report that bond markets in Asia were unable to provide a "spare tyre" during the crisis and bond yields on new issues skyrocketed.
} 
we consider the fact that some firms were relying on bonds denominated in foreign currency when the crisis burst in 1997. World bank (1999) reports that $58 \%$ of the long-term loans in the East Asia and Pacific were denominated in US dollars and over $20 \%$ in Japanese yen, whilst others were denominated in multiple currencies. The denomination of debt in foreign currencies was also extended in bond markets. After the devaluation of domestic currencies, indebted firms found it expensive to repay their foreign currency denominated debt.

In columns 1 and 2 of Table 5 we consider further the direct impact of bond issuance on survival but we make the distinction between firms that issue bond debt in foreign currency and those that issue bond debt in domestic currency. Therefore we construct the dummy Domestic which takes the value 1 if firm $i$ issues a domestic bond in year $t$, and 0 otherwise and the dummy Foreign which is equal to 1 if firm $i$ issues a foreign bond in year $t$, and 0 otherwise. We also introduce the dummy Non-issuer which takes the value 1 if firm $i$ never issues a bond throughout the sample period, and 0 otherwise. The latter dummy is the omitted category in our specification. Looking at column 1 we observe that issuing in either local or foreign currency bonds would increase survival prospects. ${ }^{10}$ Marginal effects in column 2 reveal that changing a firm's status from non-issuer to domestic (foreign) bond issuer implies an increase in the likelihood of survival by $6.34 \%$ (3.17\%). This finding corroborates the reputational effect that was identified in Table 4. Next, columns 3 and 4 focus on the impact of the crisis on the hazard of failure for domestic issuers, foreign issuers and non-issuers. To interpret the indirect effect of the crisis we interact the three dummies with the crisis time period. The results show that domestic bond issuers are shielded from the impact of the crisis, whilst foreign bond issuers are fully exposed to the Asian crisis. Marginal changes reveal that the latter group of issuers faces a $3.46 \%$ higher probability of failure during the crisis. This reflects the fact that firms with foreign denominated lending had a particular problem since debts became much more burdensome on the firms when the exchange rate collapsed. Lastly, non-issuers face the highest probability of failure which is

\footnotetext{
${ }^{10}$ The $\mathrm{p}$-value for the test of equality for the coefficients on foreign issuers and domestic issuers is 0.000 .
} 
close to $8 \% .^{11}$

\section{Robustness tests}

Overall, our results suggest that bond financing plays an important offsetting role in firm survival. In this section we subject this finding to a number of checks in order to ensure robustness. These additional checks involve estimation of our main empirical specifications controlling for bank finance and trade credit, using proportional hazard models as well as propensity score matching techniques. The section offers a test of robustness of the results in Table 4 (where we look at the direct impact of bond finance on failure and its offsetting role during the crisis) and all the reported findings are compared to Table 4.

\subsection{Controlling for additional sources of external finance}

Given that bond finance is not the only available option for firms' external finance, one concern is that other sources such as equity finance, bank finance and trade credit may have a central place in determining business failures. Our model controls for stock market reputation since we include the number of years a firm has been listed on the stock exchange, but it does not explicitly account for other options of external finance. Following Mateut et al. (2006) we consider trade credit, measured as the ratio of the firm's trade credit to its total liabilities, to account for firms that use trade credit as an additional source of external finance because they cannot get credit from banks. In addition, in the absence of data on the relationship between banks and firms we construct a bank finance variable, which is defined as the ratio of the firm's short-term debt to its total debt and it was firstly introduced by Kashyap et al. (1993), to control for the fact that Asian firms rely heavily on bank loans. We estimate therefore Equations (2.3) and (2.4) augmented with trade credit and bank finance.

We present these results in Table 6 and compare them with results in Table 4 . The

\footnotetext{
${ }^{11}$ The p-value for the test of equality for the coefficients on foreign issuers and non-issuers is 0.044 .
} 
coefficient on the bank finance is insignificant and quantitatively unimportant and this is most likely due to the fact that we have already adequately controlled for bank loans in our leverage variable. Trade credit is positive and significant indicating that higher levels of debt from trade creditors would increase the probability of failure. Again, our financial indicators appear to be important determinants of firm failures and have the expected signs. In addition, our previous results on bond finance are re-confirmed in that bond issuers are more likely to survive and remain largely unaffected during the crisis. On the contrary, non-issuers are more likely to fail during the Asian crisis. In sum, we can conclude that our core findings are not materially affected by other sources of external finance.

\subsection{Proportional hazard model}

While our empirical models explicitly control for endogeneity in our regressors using IV techniques, firm failure studies often employ Cox proportional hazard models (e.g. Audretsch and Mahmood (1995)). To ensure that our results are robust to hazard models we estimate Equations (2.3) and (2.4) using the complementary log-log model (cloglog) which is equivalent to the discrete time version of the proportional hazard model. ${ }^{12}$ Estimating the models with the complementary log-log model will allow us to capture the exact time of failure and the potential right censoring bias.

The results reported in columns 1 and 2 of Table 7 are quantitatively and qualitatively similar with those reported in Table 4. In particular, our financial indicators remain highly significant and carry the expected signs. With respect to the impact of bond finance on firm survival, we find that issuers are more likely to survive compared to non-issuers. In order to interpret the magnitude of the estimates we calculate the exponentiated coefficient of the bond dummy. This finding is economically important since the probability of failure is decreasing by $60 \%$, which is consistent with the reduction in the predicted exit probability

\footnotetext{
${ }^{12}$ Given that our data are collected on a yearly basis, the cloglog model is more appropriate compared to the Cox model. In addition, the cloglog model has the same assumptions on the coefficient vector $\hat{a}$ as the continuous-time version of the proportional hazard model (Prentice and Gloeckler (1978)).
} 
in Table 4 based on the bond dummy. In addition, we continue to find that bond issuers remain largely unaffected during the crisis, while non-issuers are more likely to fail during the same period. We therefore conclude that the offsetting role of bond finance is robust to an alternative estimation technique.

\subsection{Accounting for bond endogeneity}

It is possible that the offsetting role of bond financing in firm survival, maybe due to the endogenous nature of bond issuance decision. To address this concern we use sampled matching techniques described by Heckman et al. (1998) and recently employed in the bond IPO literature by Hale and Santos (2009). Specifically, the propensity score matching method estimates the probability of being a bond issuer conditional on observed pre-issuance characteristics using a probit model. Once the propensity scores are calculated, we use the 'caliper' matching method to select the nearest control firms in which the propensity score falls within a pre-specified radius as a match for a bond issuer. ${ }^{13}$ Therefore, we carefully construct a sample of bond issuers and matched non-issuers, and estimate Equations (2.3) and (2.4) on this matched sample using the propensity hazard model described above. ${ }^{14}$

Results reported in Table 8 are consistent with those presented in Table 4. The dummy on bond finance is negative and highly significant indicating that switching from non-issuers to issuers would directly reduce the incidence of failure. In addition, we find once again that bond-financed firms are directly shielded from the adverse effects of the crisis, while non-issuers are more likely to fail during this period.

\footnotetext{
${ }^{13}$ In order to match issuers and non-issuers we use the PSMATCH2 routine in Stata 10.1 described in Leuven and Sianesi (2003). In our analysis, the pre-specified radius is set to 0.01 .

${ }^{14}$ Since we aim to match a group of issuers and non-issuers with similar characteristics we report in the Appendix mean variable differences between the two groups of firms that were successfully matched together. It is worth noting that the matching procedure has substantially reduced the firm-level differences between issuers and non-issuers.
} 


\section{Conclusion}

Using a novel financial dataset for five Asian economies - Indonesia, Korea, Malaysia, Singapore and Thailand - that were hit the hardest during the 1997-98 crisis, we find that their survival prospects were dramatically deteriorated during this period. We find strong evidence that the crisis affected both directly and indirectly (through interactions with financial indicators) the probability of survival. Above all, we find that reputation affects positively the likelihood of survival of firms issuing bonds in either foreign or domestic currency, whereas only domestic issuers are shielded from the adverse effects of the crisis.

Our results have important policy implications. If access to bond finance is one factor that could ameliorate emerging markets crises and protect firms against failures, then the promotion of regional and well-functioning bond markets should be at the top of the policymakers' agenda. But our results are also highly relevant for western economies which now face the deepest recession since the second world war. They highlight the importance of facilitating access to liquid and resilient bond markets especially when banks decide to interrupt lines of credit during crises.

\section{References}

Alvarez, R. and Görg, H.: 2009, Multinationals and plant exit: Evidence from Chile, International Review of Economics and Finance 18, 45-51.

Audretsch, D.: 1991, Firm survival and the technological regime, Review of Economics and Statistics 73, 441450 .

Audretsch, D. and Mahmood, T.: 1995, New firm survival: New results using a hazard function, Review of Economics and Statistics 97, 97-103.

Baggs, J., Beaulieu, E. and Fung, L.: 2009, Firm survival, performance, and the exchange rate, Canadian Journal of Economics 42, 393-421.

Bernanke, B., Gertler, M. and Gilchrist, S.: 1999, The financial accelerator in a quantitative business cycle framework, in J. Taylor and M. Woodford (eds), Handbook of Macroeconomics, Vol. 1C, Elsevier Science, North Holland.

Bhattcharjee, A., Higson, C., Holly, S. and Kattuman, P.: 2009, Macroeconomic instability and business exit: Determinants of failures and acquisitions of UK firms, Economica 76, 108-131.

BIS: 2005, Developing corporate bond markets in Asia, Working Paper 26, Bank for International Settlements.

Bolton, P. and Freixas, X.: 2008, How can emerging market economies benefit from a corporate bond market?, in E. Borensztein, K. Cowan, B. Eichengreen and U. Panizza (eds), Bond Markets in Latin A merica. On the verge of a $\mathrm{B} i g$ Bang?, MIT Press. 
Borensztein, E., Eichengreen, B. and Panizza, U.: 2006, Debt instruments and policies in the new millennium: New markets and new opportunities, Working Paper 558, Inter-American Development Bank.

Bridges, S. and Guariglia, A.: 2008, Financial constraints, global engagement, and firm survival in the UK: Evidence from micro data, Scottish Journal of Political Economy 55, 444-464.

Bunn, P. and Redwood, V.: 2003, Company accounts based modelling of business failures and the implications for financial stability, Working Paper 210, Bank of England.

Burger, J., Warnock, F. and Warnock, V.: 2009, Global financial stability and local currency bond markets, Mimeo, Darden Business School, University of Virginia.

Calomiris, C., Himmelberg, C. and Wachtel, P.: 1995, Commercial paper, corporate finance, and the business cycle: a microeconomic perspective, Canergie-Rochester Conference Series on Public Policy 42, $203-250$.

Clementi, L. and Hopenhayn, H.: 2006, A theory of financing constraints and firm dynamics, Quarterly Journal of Economics 54, 229-265.

Dennis, D. and Mihov, V.: 2003, The choice among bank debt, non-bank private debt: Evidence from new corporate borrowings, Journal of Financial Economics 70, 3-28.

Diamond, D.: 1991, Monitoring and reputation: The choice between bank loans and directly placed debt, Journal of Political Economy 99, 689-721.

Dunne, T., Roberts, M. and Samuelson, L.: 1998, Patterns of firm entry and exit in US manufacturing industries, Rand Journal of Economics, 19, 495-515.

Eichengreen, B., Borensztein, E. and Panizza, U.: 2006, A tale of two markets: Bond market development in East Asia and Latin America, Occasional paper, Hong Kong Institute for Monetary Research.

Farinha, M. and Santos, J.: 2006, The survival of start-ups: Do their funding choices and bank relationships at birth matter?, Mimeo.

Fernandez, D. and Klassen, S.: 2004, Choice of currency by East Asia bond issuers, Working Paper 30, Bank for International Settlements.

Gertler, M. and Gilchrist, S.: 1994, Monetary policy, business cycles, and the behavior of small manufacturing firms, Quarterly Journal of Economics 109, 309-340.

Görg, H. and Strobl, E.: 2002, Multinational companies and indigenous development: An empirical analysis, European Economic Review 46, 1305-1322.

Görg, H. and Strobl, E.: 2003, Multinational companies, technology spillovers and plant survival, Scandinavian Journal of Economics 105, 581-595.

Greenaway, D., Gullstrand, J. and Kneller, R.: 2008, Surviving globalisation, Journal of International Economics 74, 264-277.

Hale, G. and Santos, J.: 2009, Do banks price their informational monopoly?, Journal of Financial Economics 93, $185-206$.

Heckman, J., Hidehiko, I. and Petra, T.: 1998, Matching as an econometric evaluation estimator, Review of Economic Studies 65, 261-294.

Hopehayn, R.: 1992, Entry, exit and firm dynamics in long run equilibrium, Econometrica 60, 1127-1155.

Jovanovic, B.: 1982, Selection and evolution of industry, Econometrica 50, 3-37.

Kashyap, A., Stein, J. and Wilcox, D.: 1993, Monetary policy and credit conditions: Evidence from the composition of external finance, American Economic Review 83, 78-98.

Leuven, E. and Sianesi, B.: 2003, Psmatch2: Stata module to perform full mahalanobis and propensity score matching, common support graphing, and covariate imbalance testing, Technical report, Availabale at http://ideas.repec.org/c/boc/bocode/s432001.html. 
Levin, A., Natalucci, F. and Zakrajsek, E.: 2004, The magnitude and cyclical behaviour of financial market frictions', Working Paper 2004-70, Board of Governors of the Federal Reserve System.

Maddala, G.: 1983, Limited-Dependent and Qualitative Variables in Econometrics, Vol. 3, Econometric Society Monographs, Cambridge University Press.

Mata, J. and Portugal, P.: 1994, Life duration of new firms, Journal of Industrial Economics 27, $227-243$.

Mateut, S., Bougheas, S. and Mizen, P.: 2006, Trade credit, bank lending and monetary policy transmission, European Economic Review 50, 603-629.

Myers, S. and Majluf, N.: 1984, Corporate financing and investment decisions when firms have information investors do not have, Journal of Financial Economics 131, 187-221.

Prentice, R. and Gloeckler, L.: 1978, Regression analysis of grouped survival data with application to breast cancer data, Biometrics 34, 57-67.

Rivers, D. and Vuong, H.: 1988, Limited information estimators and exogeneity tests of simultaneous probit models, Journal of Econometrics 39, 347-366.

Stinchcombe, F.: 1965, Social structure and organizations, in J. March (ed.), Handbook of Organizations, Chicago: Rand McNally.

World bank: 1999, The global depelopment finance, Annual publication, World Bank.

Zingales, L.: 1998, Survival of the fittest or the fattest? Exit and financing in trucking industry, Journal of Finance 53, 905-938.
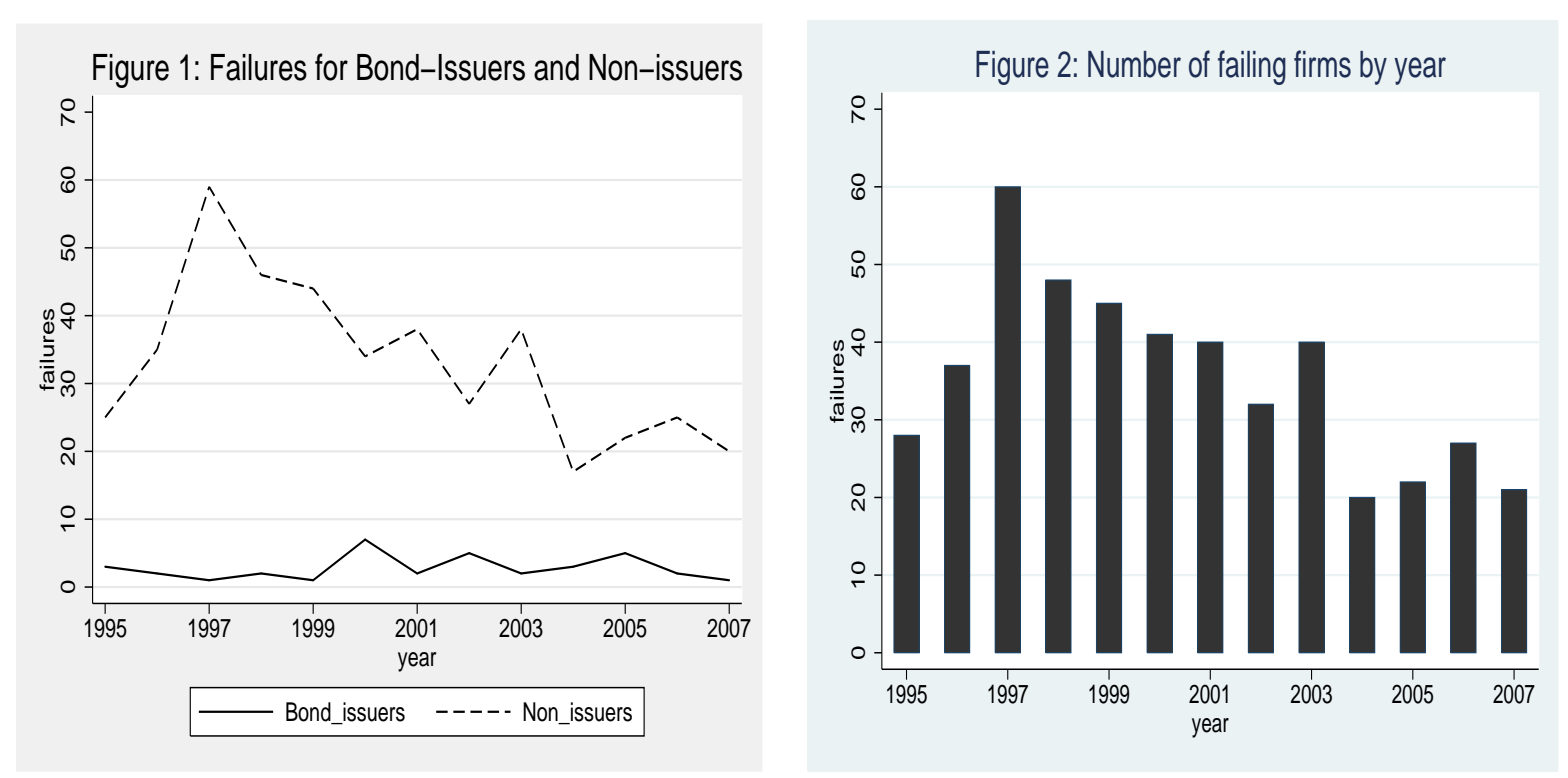
Table 1: Summary statistics

\begin{tabular}{|c|c|c|c|c|c|c|c|}
\hline & $\begin{array}{c}\text { Total Sample } \\
\text { (1) }\end{array}$ & $\begin{array}{c}\text { Fail }_{i t}=1 \\
(2)\end{array}$ & $\begin{array}{c}\text { Fail }_{i t}=0 \\
(3)\end{array}$ & $\begin{array}{c}\text { Diff. } \\
(4)\end{array}$ & $\begin{array}{c}\text { Bond }_{i t}=1 \\
(5)\end{array}$ & $\begin{array}{c}\text { Bond }_{i t}=0 \\
(6)\end{array}$ & $\begin{array}{c}\text { Diff. } \\
(7)\end{array}$ \\
\hline Fail $_{i t}$ & $\begin{array}{c}0.103 \\
(0.304)\end{array}$ & $\begin{array}{c}1.00 \\
(0.00)\end{array}$ & $\begin{array}{l}0.000 \\
(0.00)\end{array}$ & - & $\begin{array}{c}0.066 \\
(0.249)\end{array}$ & $\begin{array}{c}0.106 \\
(0.308)\end{array}$ & 0.000 \\
\hline$A g e_{i t}$ & $\begin{array}{l}14.146 \\
(4.992)\end{array}$ & $\begin{array}{c}12.671 \\
(5.152)\end{array}$ & $\begin{array}{l}14.318 \\
(4.945)\end{array}$ & 0.000 & $\begin{array}{l}13.572 \\
(4.791)\end{array}$ & $\begin{array}{l}14.199 \\
(5.004)\end{array}$ & 0.000 \\
\hline$S_{i z e_{i t}}$ & $\begin{array}{l}14.662 \\
(3.685)\end{array}$ & $\begin{array}{l}14.625 \\
(3.690)\end{array}$ & $\begin{array}{c}14.982 \\
(3.627)\end{array}$ & 0.000 & $\begin{array}{l}17.846 \\
(3.272)\end{array}$ & $\begin{array}{l}14.382 \\
(3.587)\end{array}$ & 0.000 \\
\hline Leverage $_{i t}$ & $\begin{array}{c}0.683 \\
(0.915)\end{array}$ & $\begin{array}{c}0.974 \\
(1.259)\end{array}$ & $\begin{array}{c}0.650 \\
(0.861)\end{array}$ & 0.000 & $\begin{array}{c}0.785 \\
(0.783)\end{array}$ & $\begin{array}{c}0.674 \\
(0.925)\end{array}$ & 0.000 \\
\hline Profitability $_{i t}$ & $\begin{array}{c}6.873 \\
(53.300)\end{array}$ & $\begin{array}{c}-11.614 \\
(73.505)\end{array}$ & $\begin{array}{c}9.011 \\
(50.008)\end{array}$ & 0.000 & $\begin{array}{c}1.828 \\
(37.749)\end{array}$ & $\begin{array}{c}7.317 \\
(54.433)\end{array}$ & 0.000 \\
\hline Collateral $_{i t}$ & $\begin{array}{c}0.712 \\
(0.307)\end{array}$ & $\begin{array}{c}0.583 \\
(0.386)\end{array}$ & $\begin{array}{c}0.727 \\
(0.293)\end{array}$ & 0.000 & $\begin{array}{c}0.643 \\
(0.310)\end{array}$ & $\begin{array}{c}0.718 \\
(0.306)\end{array}$ & 0.000 \\
\hline Bond $_{i t}$ & $\begin{array}{c}0.079 \\
(0.270)\end{array}$ & $\begin{array}{c}0.051 \\
(0.220)\end{array}$ & $\begin{array}{c}0.082 \\
(0.275)\end{array}$ & 0.000 & $\begin{array}{l}1.00 \\
(0.00)\end{array}$ & $\begin{array}{c}0.00 \\
(0.00)\end{array}$ & - \\
\hline Crisis $_{i t}$ & $\begin{array}{c}0.138 \\
(0.345)\end{array}$ & $\begin{array}{c}0.250 \\
(0.433)\end{array}$ & $\begin{array}{c}0.125 \\
(0.331)\end{array}$ & 0.000 & $\begin{array}{c}0.079 \\
(0.271)\end{array}$ & $\begin{array}{c}0.143 \\
(0.351)\end{array}$ & 0.000 \\
\hline Observations & 31134 & 3226 & 27908 & & 2467 & 28667 & \\
\hline
\end{tabular}

Notes: The table presents sample means. Standard deviations are reported in parentheses. Fail $i t$ is a dummy that equals 1 if firm $i$ fails in year $t$, and 0 otherwise. Age it measures the number of years a firm has been listed on the stock exchange. Size $i t$ is denoted by the $\log$ of real assets. Leverage $i$ is measured as the firm's total debt to assets ratio. Profitabilityit is the ratio of the firm's profits before interest and tax to its total assets. Collateral ${ }_{i t}$ is defined as the ratio of the firm's tangible assets over its total assets. Bond $i t$ is a dummy which takes the value 1 if firm $i$ issues a bond in year $t$, and 0 otherwise. The Crisisit is a dummy representing the Asian crisis and takes the value 1 in years 1997-98, and 0 otherwise. The subscript $i$ indexes firms, and the subscript $t$, time, where $t=1995-2007$. Variables are measured in thousands of US dollars. 
Table 2: The direct impact of the Asian crisis on survival

\begin{tabular}{|c|c|c|c|c|}
\hline & $\begin{array}{l}\text { Baseline Model } \\
\text { Endog. Probit } \\
\text { (1) }\end{array}$ & $\begin{array}{l}\text { Baseline Model } \\
\text { Marginal Changes } \\
\text { (2) }\end{array}$ & $\begin{array}{c}\text { Asian Crisis } \\
\text { Endog. Probit } \\
\text { (3) }\end{array}$ & $\begin{array}{c}\text { Asian Crisis } \\
\text { Marginal Changes } \\
\text { (4) }\end{array}$ \\
\hline Leverage $_{i t}$ & $\begin{array}{c}0.193^{* * *} \\
(11.5)\end{array}$ & 2.690 & $\begin{array}{c}0.180^{* * *} \\
(10.6)\end{array}$ & 2.445 \\
\hline Profitability $_{i t}$ & $\begin{array}{c}-0.005^{* * *} \\
(-10.3)\end{array}$ & -0.076 & $\begin{array}{c}-0.006^{* * *} \\
(-11.0)\end{array}$ & -0.081 \\
\hline Collateral $_{i t}$ & $\begin{array}{c}-0.349 * * * \\
(-7.21)\end{array}$ & -4.867 & $\begin{array}{c}-0.332^{* * *} \\
(-6.76)\end{array}$ & -4.501 \\
\hline$S_{i z e_{i t}}$ & $\begin{array}{c}-0.072^{* *} \\
(-2.02)\end{array}$ & -1.001 & $\begin{array}{c}-0.071^{* *} \\
(-1.977)\end{array}$ & -0.960 \\
\hline$S i z e_{i t}^{2}$ & $\begin{array}{c}0.003^{* * *} \\
(2.74)\end{array}$ & 0.045 & $\begin{array}{c}0.003^{* *} \\
(2.57)\end{array}$ & 0.040 \\
\hline$A g e_{i t}$ & $\begin{array}{c}-0.040^{* * *} \\
(-14.8)\end{array}$ & -0.553 & $\begin{array}{c}-0.039^{* * *} \\
(-14.5)\end{array}$ & -0.531 \\
\hline Exchange $_{t}$ & $\begin{array}{c}0.001^{* * *} \\
(5.37)\end{array}$ & 0.012 & $\begin{array}{c}0.001^{* * *} \\
(3.94)\end{array}$ & 0.010 \\
\hline$M E S_{j}$ & $\begin{array}{c}-0.348^{* * *} \\
(-7.19)\end{array}$ & -4.852 & $\begin{array}{c}-0.352^{* * *} \\
(-7.18)\end{array}$ & -4.772 \\
\hline Crisis $_{i t}$ & & & $\begin{array}{c}0.452^{* * *} \\
(14.9)\end{array}$ & 7.710 \\
\hline Log-likelihood & -6579 & & -6435 & \\
\hline Exogeneity Test(p-values) & 0.000 & & 0.000 & \\
\hline Observations & 23558 & & 23558 & \\
\hline
\end{tabular}

Notes: Endogenous Probit regression results and their marginal effects are reported. The dependent variable is a dummy equal to one if the firm fails, and zero otherwise. Leverage, profitability, collateral, size and size squared are instrumented using their lagged levels in $t-1$. The exogeneity test is a Wald test distributed as chi-squared under the null of exogeneity of the regressors. Robust z-statistics are presented in the parentheses. The following countries are included in the regressions: Indonesia, Korea, Malaysia, Singapore and Thailand. * significant at $10 \%$; ** significant at $5 \%$; ** significant at $1 \%$. Country dummies and industry dummies are included in the model. Also see notes to Table 1. 
Table 3: The indirect impact of the Asian crisis on survival

\begin{tabular}{|c|c|c|}
\hline & $\begin{array}{l}\text { Endog. Probit } \\
\text { (1) }\end{array}$ & $\begin{array}{c}\text { Marginal Changes } \\
(2)\end{array}$ \\
\hline Leverage $_{i t} *$ Crisis $_{i t}$ & $\begin{array}{c}0.718^{* * *} \\
(3.50)\end{array}$ & 8.346 \\
\hline Leverage $_{i t} *\left(1-\right.$ Crisis $\left._{i t}\right)$ & $\begin{array}{c}0.093^{* *} \\
(2.24)\end{array}$ & 1.076 \\
\hline Profitability $_{i t} *$ Crisis $_{i t}$ & $\begin{array}{l}0.002 \\
(0.47)\end{array}$ & 0.025 \\
\hline Profitability $_{i t} *\left(1-\right.$ Crisis $\left._{i t}\right)$ & $\begin{array}{c}-0.005^{* *} \\
(-2.11)\end{array}$ & -0.055 \\
\hline Collateral $_{i t} *$ Crisis $_{i t}$ & $\begin{array}{c}-1.929 * * * \\
(-7.62)\end{array}$ & -22.431 \\
\hline Collateral $_{i t} *\left(1-\right.$ Crisis $\left._{i t}\right)$ & $\begin{array}{c}-1.329^{* * *} \\
(-11.8)\end{array}$ & -15.458 \\
\hline$S_{i z e_{i t}}$ & $\begin{array}{l}-0.054 \\
(-1.23)\end{array}$ & -0.624 \\
\hline$S i z e_{i t}^{2}$ & $\begin{array}{l}0.002 \\
(1.34)\end{array}$ & 0.023 \\
\hline$A g e_{i t}$ & $\begin{array}{c}-0.037^{* * *} \\
(-11.1)\end{array}$ & -0.428 \\
\hline Exchange $_{t}$ & $\begin{array}{c}0.002^{* * *} \\
(10.4)\end{array}$ & 0.025 \\
\hline$M E S_{j}$ & $\begin{array}{c}-0.165^{* * *} \\
(-2.74)\end{array}$ & -1.914 \\
\hline Log-likelihood & -5286 & \\
\hline Exogeneity Test $(p-$ value $)$ & 0.000 & \\
\hline Observations & 20477 & \\
\hline
\end{tabular}

Notes: Endogenous Probit regression results and their marginal effects are reported. The dependent variable is a dummy equal to one if the firm fails, and zero otherwise. Leverage, profitability, collateral, size and size squared are instrumented using their lagged levels in $t-1$. The exogeneity test is a Wald test distributed as chi-squared under the null of exogeneity of the regressors. Robust z-statistics are presented in the parentheses. The following countries are included in the regressions: Indonesia, Korea, Malaysia, Singapore and Thailand. * significant at $10 \%$;* significant at $5 \%$; ** significant at $1 \%$. Country dummies and industry dummies are included in the model. Also see notes to Table 1. 
Table 4: Bond finance, survival and the Asian crisis

\begin{tabular}{|c|c|c|c|c|}
\hline & $\begin{array}{l}\text { Bond Finance } \\
\text { Endog. Probit } \\
\text { (1) }\end{array}$ & $\begin{array}{c}\text { Bond Finance } \\
\text { Marginal Changes } \\
(2)\end{array}$ & $\begin{array}{l}\text { Bond Finance* Crisis } \\
\text { Endog. Probit } \\
\text { (3) }\end{array}$ & $\begin{array}{l}\text { Bond Finance*Crisis } \\
\text { Marginal Changes } \\
\text { (4) }\end{array}$ \\
\hline Leverage $_{i t}$ & $\begin{array}{c}0.200^{* * *} \\
(11.9)\end{array}$ & 2.758 & $\begin{array}{c}0.181^{* * *} \\
(10.6)\end{array}$ & 2.452 \\
\hline Profitability $_{i t}$ & $\begin{array}{c}-0.005^{* * *} \\
(-10.3)\end{array}$ & -0.075 & $\begin{array}{c}-0.006^{* * *} \\
(-11.0)\end{array}$ & -0.079 \\
\hline Collateral $_{i t}$ & $\begin{array}{c}-0.345^{* * *} \\
(-7.10)\end{array}$ & -4.750 & $\begin{array}{c}-0.334^{* * *} \\
(-6.79)\end{array}$ & -4.516 \\
\hline Size $_{i t}$ & $\begin{array}{c}-0.119 * * * \\
(-3.28)\end{array}$ & -1.631 & $\begin{array}{c}-0.075^{* *} \\
(-2.07)\end{array}$ & -1.015 \\
\hline$S i z e_{i t}^{2}$ & $\begin{array}{c}0.006^{* * *} \\
(4.61)\end{array}$ & 0.077 & $\begin{array}{c}0.003^{* * *} \\
(2.71)\end{array}$ & 0.044 \\
\hline$A g e_{i t}$ & $\begin{array}{c}-0.040^{* * *} \\
(-14.7)\end{array}$ & -0.547 & $\begin{array}{c}-0.040^{* * *} \\
(-14.5)\end{array}$ & -0.535 \\
\hline Exchange $_{t}$ & $\begin{array}{c}0.001^{* * *} \\
(5.37)\end{array}$ & 0.011 & $\begin{array}{c}0.001^{* * *} \\
(3.99)\end{array}$ & 0.008 \\
\hline$M E S_{j}$ & $\begin{array}{c}-0.331^{* * *} \\
(-6.78)\end{array}$ & -4.552 & $\begin{array}{c}-0.348^{* * *} \\
(-7.09)\end{array}$ & -4.711 \\
\hline Bond $_{i t}$ & $\begin{array}{c}-0.493^{* * *} \\
(-9.40)\end{array}$ & -5.031 & & \\
\hline Bond $_{i t} *$ Crisis $_{i t}$ & & & $\begin{array}{l}0.193 \\
(0.76)\end{array}$ & 3.000 \\
\hline$\left(1-\right.$ Bond $\left._{i t}\right) *$ Crisis $_{i t}$ & & & $\begin{array}{c}0.466^{* * *} \\
(15.0)\end{array}$ & 8.026 \\
\hline Log-likelihood & -6532 & & -6437 & \\
\hline Exogeneity Test(p - values) & 0.000 & & 0.000 & \\
\hline Observations & 23558 & & 23558 & \\
\hline
\end{tabular}

Notes: Endogenous Probit regression results and their marginal effects are reported. The dependent variable is a dummy equal to one if the firm fails, and zero otherwise. Leverage, profitability, collateral, size and size squared are instrumented using their lagged levels in $t$-1. The exogeneity test is a Wald test distributed as chi-squared under the null of exogeneity of the regressors. Robust z-statistics are presented in the parentheses. The following countries are included in the regressions: Indonesia, Korea, Malaysia, Singapore and Thailand. * significant at $10 \%$; ** significant at $5 \%$; *** significant at $1 \%$. Country dummies and industry dummies are included in the model. Also see notes to Table 1. 
Table 5: Currency denomination of bonds, survival and the Asian crisis

\begin{tabular}{|c|c|c|c|c|}
\hline & $\begin{array}{l}\text { Bond Finance } \\
\text { Endog. Probit } \\
\text { (1) }\end{array}$ & $\begin{array}{c}\text { Bond Finance } \\
\text { Marginal Changes } \\
\text { (2) }\end{array}$ & $\begin{array}{l}\text { Bond Finance* Crisis } \\
\text { Endog. Probit } \\
\text { (3) }\end{array}$ & $\begin{array}{l}\text { Bond Finance*Crisis } \\
\text { Marginal Changes } \\
\text { (4) }\end{array}$ \\
\hline Leverage $_{i t}$ & $\begin{array}{c}0.201^{* * *} \\
(11.9)\end{array}$ & 2.737 & $\begin{array}{c}0.181^{* * *} \\
(10.6)\end{array}$ & 2.453 \\
\hline Profitability $_{i t}$ & $\begin{array}{c}-0.005^{* * *} \\
(-10.2)\end{array}$ & -0.074 & $\begin{array}{c}-0.006^{* * *} \\
(-11.0)\end{array}$ & -0.079 \\
\hline Collateral $_{i t}$ & $\begin{array}{c}-0.339 * * * \\
(-6.95)\end{array}$ & -4.617 & $\begin{array}{c}-0.333^{* * *} \\
(-6.78)\end{array}$ & -4.509 \\
\hline Size $_{i t}$ & $\begin{array}{c}-0.107^{* * *} \\
(-2.96)\end{array}$ & -1.465 & $\begin{array}{c}-0.075^{* *} \\
(-2.07)\end{array}$ & -1.011 \\
\hline$S i z e_{i t}^{2}$ & $\begin{array}{c}0.005^{* * * *} \\
(4.18)\end{array}$ & 0.070 & $\begin{array}{c}0.003^{* * *} \\
(2.72)\end{array}$ & 0.044 \\
\hline Age $_{i t}$ & $\begin{array}{c}-0.040^{* * *} \\
(-14.7)\end{array}$ & -0.543 & $\begin{array}{c}-0.039 * * * \\
(-14.5)\end{array}$ & -0.535 \\
\hline Exchange $_{t}$ & $\begin{array}{c}0.001^{* * *} \\
(5.33)\end{array}$ & 0.011 & $\begin{array}{c}0.001^{* * *} \\
(4.02)\end{array}$ & 0.008 \\
\hline$M E S_{j}$ & $\begin{array}{c}-0.342^{* * *} \\
(-6.97)\end{array}$ & -4.658 & $\begin{array}{c}-0.348^{* * *} \\
(-7.10)\end{array}$ & -4.710 \\
\hline Domestic $_{i t}$ & $\begin{array}{c}-0.792^{* * *} \\
(-9.29)\end{array}$ & -6.345 & & \\
\hline Foreign $_{i t}$ & $\begin{array}{c}-0.282^{* * *} \\
(-4.34)\end{array}$ & -3.170 & & \\
\hline Domestic $_{i t} *$ Crisis $s_{i t}$ & & & $\begin{array}{c}-0.009 \\
(-0.019)\end{array}$ & -0.128 \\
\hline Foreign $_{i t} *$ Crisis $_{i t}$ & & & $\begin{array}{l}0.219^{*} \\
(1.82)\end{array}$ & 3.462 \\
\hline Non-issuer $_{i t} *$ Crisis $_{i t}$ & & & $\begin{array}{c}0.466^{* * *} \\
(15.1)\end{array}$ & 8.027 \\
\hline Log-likelihood & -6518 & & -6433 & \\
\hline Exogeneity Test(p-values) & 0.000 & & 0.000 & \\
\hline Observations & 23558 & & 23558 & \\
\hline
\end{tabular}

Notes: Endogenous Probit regression results and their marginal effects are reported. The dependent variable is a dummy equal to one if the firm fails, and zero otherwise. Domestic $c_{i t}$ is a dummy which takes the value 1 if firm $i$ issues a domestic bond in year $t$, and 0 otherwise. Foreign $n_{i t}$ is a dummy which takes the value 1 if firm $i$ issues a foreign bond in year $t$, and 0 otherwise. $N_{\text {Non-issuer }}$ it is a dummy equal to 1 if firm $i$ never issues a bond throughout the sample period, and 0 otherwise. Leverage, profitability, collateral, size and size squared are instrumented using their lagged levels in $t$-1. The exogeneity test is a Wald test distributed as chi-squared under the null of exogeneity of the regressors. Robust z-statistics are presented in the parentheses. The following countries are included in the regressions: Indonesia, Korea, Malaysia, Singapore and Thailand. ${ }^{*}$ significant at $10 \%$; ** significant at $5 \%$; *** significant at $1 \%$. Country dummies and industry dummies are included in the model. Also see notes to Table 1. 
Table 6: Robustness: Additional sources of external finance

\begin{tabular}{|c|c|c|}
\hline & $\begin{array}{l}\text { Bond Finance } \\
\text { Endog. Probit } \\
\text { (1) }\end{array}$ & $\begin{array}{c}\text { Bond Finance*Crisis } \\
\text { Endog. Probit } \\
(2)\end{array}$ \\
\hline Leverage $_{i t}$ & $\begin{array}{c}0.226^{* * *} \\
(12.4)\end{array}$ & $\begin{array}{c}0.207^{* * *} \\
(11.2)\end{array}$ \\
\hline Profitability & $\begin{array}{c}-0.006^{* * *} \\
(-8.87)\end{array}$ & $\begin{array}{c}-0.006^{* * *} \\
(-9.66)\end{array}$ \\
\hline Collateral $_{i t}$ & $\begin{array}{c}-0.197^{* * *} \\
(-3.43)\end{array}$ & $\begin{array}{c}-0.180^{* * *} \\
(-3.12)\end{array}$ \\
\hline$S_{i z e_{i t}}$ & $\begin{array}{l}-0.038 \\
(-0.89)\end{array}$ & $\begin{array}{l}0.007 \\
(0.17)\end{array}$ \\
\hline$S i z e_{i t}^{2}$ & $\begin{array}{c}0.004^{* * *} \\
(2.75)\end{array}$ & $\begin{array}{l}0.001 \\
(1.07)\end{array}$ \\
\hline Age $_{i t}$ & $\begin{array}{c}-0.029 * * * \\
(-9.64)\end{array}$ & $\begin{array}{c}-0.029 * * * \\
(-9.66)\end{array}$ \\
\hline Exchange $_{t}$ & $\begin{array}{c}0.001^{* * *} \\
(5.15)\end{array}$ & $\begin{array}{c}0.001^{* * *} \\
(3.87)\end{array}$ \\
\hline$M E S_{j}$ & $\begin{array}{c}-0.293^{* * *} \\
(-5.54)\end{array}$ & $\begin{array}{c}-0.306^{* * *} \\
(-5.78)\end{array}$ \\
\hline Trade $_{i t}$ & $\begin{array}{c}0.399 * * \\
(2.48)\end{array}$ & $\begin{array}{c}0.428^{* * *} \\
(2.63)\end{array}$ \\
\hline Bank $_{i t}$ & $\begin{array}{l}0.026 \\
(0.34)\end{array}$ & $\begin{array}{l}0.026 \\
(0.34)\end{array}$ \\
\hline Bond $_{i t}$ & $\begin{array}{c}-0.460^{* * *} \\
(-8.42)\end{array}$ & \\
\hline Bond $_{i t} *$ Crisis $_{i t}$ & & $\begin{array}{l}0.273 \\
(1.05)\end{array}$ \\
\hline$\left(1-\right.$ Bond $\left._{i t}\right) *$ Crisis $_{i t}$ & & $\begin{array}{c}0.428^{* * *} \\
\quad(12.6)\end{array}$ \\
\hline Log - likelihood & -5467 & -5404 \\
\hline Exogeneity Test $(p-$ values $)$ & 0.000 & 0.000 \\
\hline Observations & 19888 & 19888 \\
\hline
\end{tabular}

Notes: Endogenous Probit regression results and their marginal effects are reported. The dependent variable is a dummy equal to one if the firm fails, and zero otherwise. Trade is the ratio of the firm's trade credit over its total liabilities. Bank is defined as the ratio of the firm's short term debt over its total debt. Leverage, profitability, collateral, bank, trade, size and size squared are instrumented using their lagged levels in $t-1$. The exogeneity test is a Wald test distributed as chi-squared under the null of exogeneity of the regressors. Robust z-statistics are presented in the parentheses. The following countries are included in the regressions: Indonesia, Korea, Malaysia, Singapore and Thailand. ${ }^{*}$ significant at $10 \%$; ${ }^{* *}$ significant at $5 \%$; ${ }^{* *}$ significant at 1\%. Country dummies and industry dummies are included in the model. Also see notes to Table 1. 
Table 7: Robustness: Proportional hazard model

\begin{tabular}{|c|c|c|}
\hline & $\begin{array}{c}\text { Bond Finance } \\
(1)\end{array}$ & $\begin{array}{c}\text { Bond Finance* Crisis } \\
(2)\end{array}$ \\
\hline Leverage $_{i t}$ & $\begin{array}{c}0.230^{* * *} \\
(14.1)\end{array}$ & $\begin{array}{c}0.217^{* * *} \\
(13.2)\end{array}$ \\
\hline Profitabilityit & $\begin{array}{c}-0.004^{* * *} \\
(-11.5)\end{array}$ & $\begin{array}{c}-0.004^{* * *} \\
(-10.8)\end{array}$ \\
\hline Collateral $_{i t}$ & $\begin{array}{c}-0.661^{* * *} \\
(-9.84)\end{array}$ & $\begin{array}{c}-0.673^{* * *} \\
(-9.94)\end{array}$ \\
\hline$S i z e_{i t}$ & $\begin{array}{c}-0.115^{* *} \\
(-2.02)\end{array}$ & $\begin{array}{l}-0.066 \\
(-1.17)\end{array}$ \\
\hline$S i z e_{i t}^{2}$ & $\begin{array}{c}0.006^{* * *} \\
(3.41)\end{array}$ & $\begin{array}{l}0.003^{*} \\
(1.84)\end{array}$ \\
\hline$A g e_{i t}$ & $\begin{array}{c}-0.082^{* * *} \\
(-18.4)\end{array}$ & $\begin{array}{c}-0.083^{* * *} \\
(-18.3)\end{array}$ \\
\hline Exchange $_{t}$ & $\begin{array}{l}0.000 \\
(0.84)\end{array}$ & $\begin{array}{l}-0.000 \\
(-0.34)\end{array}$ \\
\hline$M E S_{j}$ & $\begin{array}{c}-0.533^{* * *} \\
(-6.49)\end{array}$ & $\begin{array}{c}-0.549 * * * \\
(-6.69)\end{array}$ \\
\hline Bond $_{i t}$ & $\begin{array}{c}-0.870^{* * *} \\
(-9.42)\end{array}$ & \\
\hline Bond $_{i t} *$ Crisis $_{i t}$ & & $\begin{array}{l}0.277 \\
(1.44)\end{array}$ \\
\hline$\left(1-\right.$ Bond $\left._{i t}\right) *$ Crisis $_{i t}$ & & $\begin{array}{c}0.684^{* * *} \\
(14.8)\end{array}$ \\
\hline $\begin{array}{l}\text { Log - pseudolikelihood } \\
\text { Observations }\end{array}$ & $\begin{array}{l}-7841 \\
26852\end{array}$ & $\begin{array}{l}-7799 \\
26852\end{array}$ \\
\hline
\end{tabular}

Notes: Complementary log-log regression results are reported. The dependent variable is a dummy equal to one if the firm fails, and zero otherwise. Robust z-statistics are presented in the parentheses. The following countries are included in the regressions: Indonesia, Korea, Malaysia, Singapore and Thailand. * significant at $10 \%$; ** significant at $5 \%$; *** significant at $1 \%$. Country dummies and industry dummies are included in the model. Also see notes to Table 1. 
Table 8: Robustness: Accounting for bond endogeneity in a matched sample

\begin{tabular}{|c|c|c|}
\hline & $\begin{array}{l}\text { Bond Finance } \\
\text { (1) }\end{array}$ & $\begin{array}{l}\text { Bond Finance* Crisis } \\
(2)\end{array}$ \\
\hline Leverage $_{i t}$ & $\begin{array}{c}0.384^{* * *} \\
(8.11)\end{array}$ & $\begin{array}{c}0.346^{* * *} \\
(7.17)\end{array}$ \\
\hline Profitability $_{i t}$ & $\begin{array}{c}-0.004^{* * *} \\
(-3.61)\end{array}$ & $\begin{array}{c}-0.003^{* * *} \\
(-2.77)\end{array}$ \\
\hline Collateral $_{i t}$ & $\begin{array}{r}-0.421^{*} \\
(-1.71)\end{array}$ & $\begin{array}{l}-0.278 \\
(-1.18)\end{array}$ \\
\hline$S_{i z e_{i t}}$ & $\begin{array}{l}0.414^{*} \\
(1.89)\end{array}$ & $\begin{array}{l}0.290 \\
(1.27)\end{array}$ \\
\hline$S i z e_{i t}^{2}$ & $\begin{array}{l}-0.009 \\
(-1.44)\end{array}$ & $\begin{array}{l}-0.006 \\
(-0.92)\end{array}$ \\
\hline$A g e_{i t}$ & $\begin{array}{c}-0.079^{* * *} \\
(-6.21)\end{array}$ & $\begin{array}{c}-0.080^{* * *} \\
(-5.99)\end{array}$ \\
\hline Exchange $_{t}$ & $\begin{array}{l}0.000 \\
(0.34)\end{array}$ & $\begin{array}{l}-0.000 \\
(-0.71)\end{array}$ \\
\hline$M E S_{j}$ & $\begin{array}{c}-0.433^{* *} \\
(-2.50)\end{array}$ & $\begin{array}{c}-0.531^{* * *} \\
(-3.12)\end{array}$ \\
\hline Bond $_{i t}$ & $\begin{array}{c}-0.891 * * * \\
(-8.07)\end{array}$ & \\
\hline Bond $_{i t} *$ Crisis $_{i t}$ & & $\begin{array}{l}0.265 \\
(1.23)\end{array}$ \\
\hline$\left(1-\right.$ Bond $\left._{i t}\right) *$ Crisis $_{i t}$ & & $\begin{array}{c}1.196^{* * *} \\
(8.82)\end{array}$ \\
\hline $\begin{array}{l}\text { Log-pseudolikelihood } \\
\text { Observations }\end{array}$ & $\begin{array}{r}-1148 \\
4160\end{array}$ & $\begin{array}{r}-1148 \\
4160\end{array}$ \\
\hline
\end{tabular}

Notes: Complementary log-log regression results on the matched sample are reported. The dependent variable is a dummy equal to one if the firm fails, and zero otherwise. Robust z-statistics are presented in the parentheses. The following countries are included in the regressions: Indonesia, Korea, Malaysia, Singapore and Thailand. ${ }^{*}$ significant at $10 \%$; ${ }^{*}$ significant at $5 \%$; *** significant at $1 \%$. Country dummies and industry dummies are included in the model. Also see notes to Table 1. 
Table A-1: Mean variable differences between bond issuers and non-issuers in the pre-issuance period, matched sample.

\begin{tabular}{lcccccc}
\hline & $\begin{array}{c}\text { Mean } \\
\text { Treated }\end{array}$ & $\begin{array}{c}\text { Mean } \\
\text { Control }\end{array}$ & $\begin{array}{c}\% \\
\text { Bias }\end{array}$ & $\begin{array}{c}\text { \%Bias } \\
\text { Reduction }\end{array}$ & t-test & $\begin{array}{c}\text { t-test } \\
(\mathrm{p} \text {-value })\end{array}$ \\
\hline Leverage $_{i t}$ & 0.739 & 0.718 & 2.8 & 80.4 & 0.87 & 0.384 \\
Collateral $_{i t}$ & 0.636 & 0.634 & 0.8 & 97.0 & 0.26 & 0.795 \\
Profitability $_{i t}$ & 1.447 & 1.837 & 0.9 & 91.1 & 0.33 & 0.743 \\
Size $_{i t}$ & 17.668 & 17.71 & 1.3 & 98.9 & 0.41 & 0.680 \\
Size $_{i t}$ & 322.88 & 325.18 & 2.2 & 98.1 & 0.66 & 0.511 \\
Age $_{i t}$ & 13.643 & 13.47 & 3.6 & 73.1 & 1.13 & 0.260 \\
MES $_{j}$ & 13.484 & 13.467 & 2.6 & 85.2 & 0.80 & 0.426 \\
Exchange $_{t}$ & 576.41 & 612.68 & 7.0 & 88.0 & 2.10 & 0.035 \\
\hline
\end{tabular}

Notes: See notes to Table 1 for definition of the variables including in the matching. 